Article

\title{
Assessing the Formal and Informal Waste Recycling Business Processes through a Stakeholders Lens in Pakistan
}

\author{
Muhammad Nawaz ${ }^{1}$, Muhammad Tariq Yousafzai ${ }^{2}{ }^{(1)}$, Salim Khan $^{3}$, Wisal Ahmad ${ }^{1}$, Muhammad Salman ${ }^{1}$, \\ Heesup Han 4,*(D), Antonio Ariza-Montes ${ }^{5}$ (D) and Alejandro Vega-Muñoz ${ }^{6}$ (D) \\ 1 Institute of Business Studies, Kohat University of Science and Technology, \\ Khyber Pakhtunkhwa 26000, Pakistan; Muhammad.nawaz@kust.edu.pk (M.N.); dr.wisal@kust.edu.pk (W.A.); \\ msalman@kust.edu.pk (M.S.) \\ 2 Centre for Management and Commerce (CMC), University of Swat, Mingora 19130, Pakistan; \\ muhammadtariq@uswat.edu.pk \\ 3 Riphah school of Leadership, Faculty of Management Science (FMS), Riphah International University, \\ Malakand Campus, Chakdara 18300, Pakistan; salimuom@yahoo.com \\ 4 College of Hospitality and Tourism Management, Sejong University, Seoul 05006, Korea \\ 5 Social Matters Research Group, Universidad Loyola Andalucía, C/Escritor Castilla Aguayo, \\ 414004 Córdoba, Spain; ariza@uloyola.es \\ 6 Public Policy Observatory, Universidad Autónoma de Chile, 425 Pedro de Valdivia Avenue, Providencia, \\ Santiago 7500912, Chile; alejandro.vega@uautonoma.cl \\ * Correspondence: heesup.han@gmail.com
}

check for updates

Citation: Nawaz, M.; Yousafzai, M.T.; Khan, S.; Ahmad, W.; Salman,

M.; Han, H.; Ariza-Montes, A.; Vega-Muñoz, A. Assessing the Formal and Informal Waste Recycling Business Processes through a Stakeholders Lens in Pakistan. Sustainability 2021, 13, 11717. https:/ / doi.org/10.3390/su132111717

Academic Editor: Antonis A. Zorpas

Received: 16 September 2021

Accepted: 18 October 2021

Published: 23 October 2021

Publisher's Note: MDPI stays neutral with regard to jurisdictional claims in published maps and institutional affiliations.

Copyright: (C) 2021 by the authors Licensee MDPI, Basel, Switzerland. This article is an open access article distributed under the terms and conditions of the Creative Commons Attribution (CC BY) license (https:// creativecommons.org/licenses/by/ $4.0 /)$.

\begin{abstract}
With this study, we aim to assess integration possibilities of formal and informal waste management approaches in a low-income country context by using recycling as a tool towards sustainability. Using a holistic approach, this study examines both formal and informal aspects of recycling value chains through a stakeholder lens. Pakistan is far from being a circular economy, as evident from the dismal levels of municipal solid waste collection and recycling. This problem calls for the effective integration of formal and informal recycling business processes to fill the void. With this study, we seek to assess various aspects of formal and informal waste recycling in Pakistan through an inductive qualitative research design by examining the case of one of the most populous cities, Lahore, in the Punjab province of Pakistan. Equal representation to various stakeholders is accorded, with 25 interviews each with managers of private companies, public companies, waste pickers and scrap dealers in the target area. The study highlights that recycling sector in Pakistan is completely informal and unregulated with no or little support available due to a lack of funds and systematic planning. The empirical evidence suggests that the formal sector lacks the capacity for proper waste disposal of total waste generated. The recycling aspects are left to informal sector stakeholders who improvise to extract value from MSW in an entrepreneurial manner. The formal sector holds a bias towards informal stakeholders due to the fact that their work also serves as a theft bargain and resale platform under the guise of waste collection and recycling. The study highlights the most and least sought after recyclables, identifies gray channel markets of spare parts, metal recycling and counterfeit products, and practices of adulteration in the target area. This study recommends as a policy input, to overcome bias towards the informal sector, the creation of a central recycling commission to overlook and regulate the affairs of hitherto unregulated and informal municipal solid waste and recycling value chains.
\end{abstract}

Keywords: formal recycling; informal recycling; entrepreneurs; sustainability; salient stakeholders; waste pickers sustainopreneurs; public-private partnerships

\section{Introduction}

Waste diversion and recycling has become a wicked problem faced by humans mainly due to incomplete or contradictory knowledge and a larger number of stakeholders [1]. 
These problems are further interconnected with other problems such as population explosion, urbanization, and industrialization, which cause accelerated landfill accumulation with little or no formal policies for waste diversion and recycling in many parts of world [2]. According to [3], Pakistan is the fifth most populous country, but despite this, the corresponding waste generation per capita is lower than many developed countries. The real issue is mismanagement of waste through formal mechanisms, which is a source of grave concern for municipal authorities in Pakistan as they are overwhelmed by the sheer volume of waste disposal workloads, leaving recycling to be handled by informal stakeholders in an entrepreneurial manner, who oftentimes work without any supervision or monitoring. The symbiotic relationship of formal and informal municipal solid waste management (MSWM) stakeholders and their integration exhibit varying characteristics and levels of interdependence across regions [4]. In developing countries, mostly government interventions strive for inclusion and integration of shadow economy stakeholders in recycling and waste management value chains [5]. In developed countries, cooperative industrial symbiosis exists as a business strategy to achieve efficiencies in solid waste management [6]. Public-private partnerships are frequently proposed as a remedial measure to ameliorate the quality of services, minimize the cost of MSWM and create a formal connection between the public and private sector for improved productivity [7]. Still, the majority of the work is performed by autonomous waste pickers in the recycling sector in Pakistan, who act as helping hand to the government and are characterized by traits such as low technology, lack of work permits, small-scale work, unregistered operations, labor-intensive work and self-administered working [8,9]. The informal sector work, which is unregulated due to lack of licenses, incur no taxes and as a result is kept outside formal welfare schemes of the government [10]. Thus, it can be said that in Pakistan, the recycling and MSWM practices are haphazard, segregated and devoid of systematic integration to achieve synergistic complementarities towards the attainment of SDGs.

On the one hand, the formal sector of MSWM comprises public service providers and private companies. On the other hand, waste picker sustainopreneurs, itinerant waste cart holders and small unregistered shops who buy recyclables as a side business represent the informal sector $[8,11]$. In the informal sector, recycling work is performed by waste pickers and scavengers, most of whom are from economically marginalized minorities or refugee backgrounds [12]. The conventional ways of managing and recycling in Pakistan are below par, as almost 50 percent of MSW is left unattended by the formal sector [5]. In Pakistan, garbage collection ranges from 57 percent in Lahore to around 40 percent in other major cities of Pakistan [13]. For certain specific items, many countries such as Sweden proclaim an impressive recycling rate of up to 99 percent, followed by Germany with 87 percent and Singapore with 60 percent $[9,14,15]$. These impressive numbers do not reveal the notion that in Sweden, the 99 percent recycling rate also includes controlled incineration as a form of recycling [16]. Improper recycling practices, without integrating formal and informal stakeholders, can possibly impact not only Pakistan but also pollute the common global ecosystem. Moreover, in certain cases, informal ways of cleansing and recycling can actually inflict more harm than good on the environment [17]. Against the backdrop of the preceding discussion, we see inefficiencies in MSWM and recycling, a gap which this study strives to fill through integration possibilities of formal and informal stakeholders in Pakistan.

The formal waste collection stakeholders view informal garbage collectors as unhygienic, backwards and not in alignment with up-to-date MSWM systems [18]. Such contempt and disdain of services of the informal sector lowers the morale of individuals who act as waste picker sustainopreneurs [8]. Yet, the formal authorities do not shy away from taking credit for their work in grandiose processes of reporting self-progress. Moreover, the informal work is highly invisible due to a taboo associated with cleaning work in Muslim faith countries. Thus, efforts of waste value chain intermediaries are seldom documented, which serves as a major hindrance for their transition to the formal sector through a policy framework [18]. The complete omission of the services of shadow stakeholders 
will strip them of their sole source of income, and if the informal sector is excluded from recycling, this may overburden formal stakeholders [19]. The study defines the formal and informal sector and its characteristics, along with the challenges it faces in terms of recycling. The objective is to suggest strategies for the possible integration of the informal sector with formal waste management in order to create a more sustainable recycling system for Pakistan's urban areas through inputs on policy level. Hence, the central research question of the study is, "How can informal and formal waste recycling stakeholders can be integrated in mutually beneficial ways for sustainable MSWM systems?"

\section{Literature Review}

\subsection{Garbage Recycling in Pakistan by the Informal and Formal Sector Stakeholders}

In Pakistan, people living below the base of the pyramid of society pick up garbage and scavenge it for recyclable items to cover their living expenses in a manner so subtle that it is hardly observable [20]. They sometimes use loud-speaker voice amplifiers to collect recyclables through short and well-choreographed shout outs in streets and quickly disappear due to their undue nuisance in the form of noise. Hundreds of families in Pakistan have resorted to garbage picking in urban areas in order to survive [21], which is in contrast to 2 percent of people in Latin America [4]. Garbage picking plays an important role in keeping the cities clean, enhances the beauty of the areas and is favorable for the health of the people. Informal garbage pickers often form a social circle of their own or belong to minorities, such as the unprivileged Afghan immigrants in Lahore, or the people living in the slums and ghettos of Karachi [22]. In addition, the tricyclists, scavengers on the streets, pick-up traders with voice amplifiers and collection groups are also the main informal collectors. They collect recyclable waste directly from several sources around the cities and the remainder is searched and taken up from the landfill by scavengers. Moreover, recycling activities of waste materials by the Lahore Waste Management Company (LWMC) in the city where this study was conducted not only decrease the volume of environmental pollutants and solid waste, but also improve the economic conditions and create job opportunities. It has been estimated that LWMC is handling approximately 27 percent less waste disposal and collection due to the co-existence of informal stakeholders, who collect recyclables prior to formal collection services. Such reductions in waste disposal are also observed in other cities of developing countries, such as Delhi in India, where a major portion of recyclables is diverted prior to formal collection [23]. Likewise, a similar system of shadow workers exists, albeit invisibly, in other developing countries with slight variations, yet for similar economic reasons. This system is established in the least developed nations to enhance the recycling volumes in a self-organized manner that complements the formal sector [13].

\subsubsection{Migratory Garbage Buyers as Informal Stakeholders}

This category of informal stakeholders is one of the most vulnerable groups of people, who, due to their personal household and cattle food insecurity, earn livelihoods through garbage collection [24]. This category includes refugees or asylum seekers who collect garbage from households in order to find recyclables as well as extract cattle fodder from kitchen waste for their alternative livelihood source to be sold during the Eid Al Azha animal sacrifice in Muslim countries [25]. These people had fled war-torn countries, such as Afghanistan, Somalia, Syria, Yemen and Iraq and delve in the saleable practice of garbology which is not usually a priority of host country residents [26]. Their immediate expectation is additional cash in hand to support their family members back home for which they often risk their asylum claims. This is because many countries prohibit work during the process of asylum-seeking [27]. Such people often belong to conflict zones, lack residence permits and have low language proficiency and inadequate skills, which compel them to work at the base of the poverty pyramid. Such people act as accidental sustainopreneurs or environmentalists and can be easily found near border areas of countries, although their informal presence is more visible in developing countries [8]. After collection, the material 
is then taken to a recycling shop, known as kbaariya working in kabaarkhana, although the scale of kbaariya businesses may be part-time on small streets and full-time businesses are mostly found near central markets and roads, as logistics are important in scrap industry. These people work in deplorable conditions, yet have eco-friendly livelihoods, which makes them important stakeholders known as sustainopreneurs in domains of collection and recycling of MSWM [8]. These informal stakeholders possess dual identities and some ascend to a higher level to purchase cargo vehicles which are then used to transport recyclable materials in larger quantities [28].

\subsubsection{Street Garbage Pickers as Informal Stakeholders}

These proletariat workers use garbage picking as a survival strategy by collecting recuperated material from streets and public dustbins prior to the formal collection [29]. The discarded waste picking allows cash in hand as an extended financial life line to these individuals who are hard-pressed to find work in the formal economy [19]. In countries such as Pakistan, waste-related work is considered a taboo, as in most other Muslim countries. Some addicts perform this work but delve in stealing activities under the guise of scavenging the littered items which goes unnoticed and provides quick cash [8]. There is a correlation between the survivalist nature of street picking and poverty because as long as there is poverty, there will always be street garbage pickers [30]. In other words, these people are caught up in a dualistic barrier as they are put into an environment for their livelihood which is unsustainable but at the same time they are trapped in said environment. Despite the contributions of the informal sector in Pakistan, the waste collection rates remain low. A whopping 64 percent of garbage comprises organic waste, followed by 27 percent recyclable materials and inert waste represents 9 percent of all materials [31]. There is an interesting correlation between street pickers and public litter patterns, as a recycling fervor, if inculcated, may adversely impact people working in small-scale business operations. This leaves room for policy makers and decisions makers to strike a delicate balance, by rising above paradoxical stakeholders' interests, while ensuring sustainability through the integration of formal and informal mechanisms to achieve SDGs.

\subsubsection{Crew of Municipal Garbage Collection as Formal Stakeholders}

In Pakistan, a pensionable job is the most trodden path and a standard of prestige in the eyes of the general public, although salaries of the public sector are comparatively lower [32]. Politicians are interested in low mechanization to allow room for the creation of more jobs for personnel of municipal governments [33]. There is greater variation in perceptions of self-reported work carried out by workers in both the public and private sectors [34], although in Pakistan, private sector workers are perceived as hard working, while government servants are stereotyped as hardly working. However, the positive societal narrative about public jobs and discourse about the unhygienic nature of work life in the sanitation sector creates a paradoxical situation, which serve as an attitudinal hindrance in the proper dispensing of duties even after the recruitment of MSW and sanitary personnel. Moreover, these workers are concerned with neither source segregation nor diversion of recyclables, but responsible only for the transportation of municipal solid waste (MSW) to the nearest dumping sites and landfills. The work of municipal crews employed for MSWM is characterized by institutional inefficiencies and is quite disorganized due to a variety of reasons. Inefficiencies in their working mars waste recycling efforts and results in blockades of drainage systems, inundating homes and commercial buildings during recurrent monsoon rain spells [35].

\subsubsection{Garbage Collection from Dumps with Scavengers as Stakeholders}

Scavenging from dumps and landfills is a common informal practice observed throughout both the developed and developing world [36]. According to [37], these people live below the bottom of the pyramid in urban areas, earning less that USD 5 per day. These 
people are involved in post-dump garbage collection during the day before the garbage is buried under soil or burnt at night. These stakeholders are characterized as rendering services to buyers of recuperated anthropogenic material and industrial value chain members without any contractual obligations on a cash-in-hand basis, similar to gig economy workers [38]. This activity is prevalent in several developing countries, including Pakistan across all its major cities, and is often performed by people who live nearby in shacks made from recycled wood in unhygienic conditions in slums near Lahore city. As the distance from waste generation points to waste accumulation points such as dumps rises, the number of aggregate waste pickers per unit area also rises proportionally due to reduced transportation costs. The nature of the work comprises onsite sorting, storage, handling, resource recovery and recycling [39].

\subsection{Integration of Formal and Informal Waste Management Stakeholders}

The formal sector often derives its approaches to waste management from developed countries, which bear low resemblance and transferability to informal ways of recycling in developing countries [35]. As a general rule of thumb, if the informal garbage collecting sector is less orderly, the people who are associated with this activity will be less likely to create more value out of the material they recycle, and will provide the intermediaries with a greater chance to exploit their weak position [40]. Garbage collection and recycling across the world have their own value chain stakeholders that span from suppliers-supplier to the buyers-buyer of recyclable items [41]. At times, there is not a visible chain that links informal garbage collectors with buyers, who include junkyards, wholesalers, brokers and processors, and who might be associated with informal or formal authorities. The informal sector is often excluded by the authorities in various planning project cycles (PC1) when preparing a formal mechanism to create solid waste management plan, policies and practices. This results in inefficient systems, which are costly to operate from a waste collection, transportation and disposal perspective [42]. In particular, the privatization of MSWM to exclude the informal sector can wreak havoc on the scavengers and collectors for whom the garbage picking and recycling is a sole source of income [43]. Inwardly, it can also mean additional work for formal stakeholders such as municipality workers and private formal sector stakeholders. Against the backdrop of the preceding discussion, it is important to accord priority consideration to the participation of all formal and informal stakeholders as key players in sustainable waste and recycling management [44]. It is pertinent to mention that recyclable waste recycling should promote source separation to induce greater efficiencies in recycling processes [45]. Thus, for improving formal and informal waste management with respect to recycling in developing countries such as Pakistan, inclusive policy making in the form of an all-encompassing stakeholder framework is needed.

\section{Methodology}

\subsection{Data}

The data in study were collected during the process of a municipal solid waste categorization and productivity project in 12 districts of Punjab as part of an ongoing independent project. The study utilizes an interpretivist research design which is also known as non-positivist research in an effort to construct context-specific reality [46]. Through interpretivism, the context specific truth is unveiled as the participants of study are human beings who are able to interpret themselves and their environment, unlike inanimate objects used in naturalistic research designs [47]. The issue of recycling and its transition to formal integration mechanisms presents an indeterminate situation due to its complex and uncertain nature having repercussions for sustainability across borders [48] Thus, unsustainable practices such as random recycling of municipal solid waste in Pakistan creates social, environmental and economic deadlocks which can be termed as wicked problems due to their challenging and context specific nature $[49,50]$. With this study, we seek to assess various aspects of formal and informal waste recycling in Pakistan through 
an inductive qualitative research design (interpretive) by examining the case of one of the most populous cities, Lahore, in the Punjab province of Pakistan. Equal representation of various stakeholders is accorded with 25 interviews each with managers of private companies, public companies, autonomous waste pickers and scrap dealers.

\subsection{Sampling Procedure}

Trust with respondents was developed through ongoing interactions for four years with managers of formal and informal solid waste management and recycling companies including but not limited to Ozkartallar Compak Joint Venture, A.T. Waste Management, Lahore Waste Management Company, OzPak Company and the Gujranwala Waste Management Company and Water and Sanitation Agency, Lahore. The data were collected from the companies with respect to their year of incorporation, daily capacity and operating areas, as indicated in Table 1. A purposive sampling procedure was used for conducting interviews with both formal and informal stakeholders. The sample size of 25 interviews within a category is recommended in light of the best practices recommended by [51] and [52], cited in [53]. However, in qualitative research, the point of the theoretical situation, which refers to phenomena where new insights from interviews cease to emerge despite the conduct of additional interviews, is taken into consideration [8]. As a part of a strict criterion for the recruitment of interviewees, it was mandatory for the interviewee/manager to have at least three years of experience working. Both male and female participants were interviewed and on average, each interview took $45 \mathrm{~min}$. The interviews were transcribed by the lead researcher with pseudonyms given to interviewees.

Table 1. Details of five companies from which data were collected.

\begin{tabular}{lccccc}
\hline Sr. & Name & Founding Year & City & Services & Daily Waste in Tons \\
\hline 1 & Lahore Waste Management & 2010 & Lahore & Overall Waste & 8340 \\
2 & OzPak & 2009 & Various parts of Punjab & Overall Waste & 10,510 \\
3 & Ozkatallar & 2008 & Various parts of Punjab & Overall Waste & 4583 \\
4 & Gujranwala Waste & 2004 & Gujranwala & Overall Waste & 2841 \\
5 & A.T waste & 2012 & Various parts of Pakistan & Industrial wastes & 1581 \\
\hline
\end{tabular}

\subsection{Process of Interviews}

The interview guide, as shown in Table 2, was recursively refined as we moved ahead in the data collection. The interview guide was translated into the local language for the ease of respondents as the majority of waste pickers and scrap dealers are illiterate. Ethical considerations were taken into consideration as naiveté about the ethics of qualitative research is in itself unethical practice [54]. Informed consent was sought from interviewees to ensure ethical sensitivity about the purpose of the research and confidentiality was maintained through assigned pseudonyms in lieu of real names. Moreover, additional supportive data were also collected by exploring the facts provided by the Bureau of Statistics, Pakistan, which can be seen in Table 3; Table 4. Table 3 accounts for the percentage and ratio of the nature of waste collected on a daily basis. Table 4 shows details about daily solid waste generation and populations of major cities of Pakistan in order to identify the effectiveness of formal companies and to assess their integration potential with informal stakeholders of recycling in a complementary manner. 
Table 2. Selected questions from interview guide or interview protocol.

\begin{tabular}{|c|c|}
\hline Sr. & \\
\hline 1 & What would you like to tell us about your company's ways of managing waste? \\
\hline 2 & How do you see the company's present waste managing and recycling methods? \\
\hline 3 & $\begin{array}{c}\text { What would you share about the latest technologies to dispose of or recycle waste? Does your company use these } \\
\text { methods presently? }\end{array}$ \\
\hline 4 & $\begin{array}{c}\text { Is the company planning to bring any technological change in the near future to improve recycling? If yes, what would } \\
\text { that be? }\end{array}$ \\
\hline 5 & $\begin{array}{l}\text { How would you evaluate the incorporation of informal ways of waste management in this company? Does the informal } \\
\text { waste recycling offer any support, in your view? }\end{array}$ \\
\hline 6 & What would be the costs to include the people who pick garbage informally and recycle it? \\
\hline 7 & $\begin{array}{c}\text { Would you prefer to hire such labor on daily wages or on monthly wages? In both cases, what would be the costs for } \\
\text { the company? }\end{array}$ \\
\hline 8 & How do you see the future of recycling in Pakistan? \\
\hline 9 & Please elaborate informal value chain stakeholders' role in the recycling context? \\
\hline 10 & What is the margin of various intermediaries in solid waste management and recycling? \\
\hline
\end{tabular}

Table 3. Composition of municipal solid waste (MSW) in Pakistan (Physical Composition of MSW by Percent) According to Bureau of Statistics.

$\begin{array}{cc}\text { Ash, Bricks and Dirt } & 18 \% \\ \text { Glass } & 6 \% \\ \text { Textile } & 2 \% \\ \text { Cardboard } & 7 \% \\ \text { Food Waste } & 30 \% \\ \text { Leather } & 1 \% \\ \text { Paper } & 6 \% \\ \text { Plastic } & 9 \% \\ \text { Rubber } & 1 \% \\ \text { Metal } & 4 \% \\ \text { Wood } & 2 \% \\ \text { Yard Waste } & 14 \%\end{array}$

\section{Stakeholders Data Analysis and Results}

The empirical data collected from participants resulted in the identification of a number of primary and secondary stakeholders. It is obvious that stakeholders differ in regards to their role, relevance and engagement levels. Moreover, direct and indirect stakeholders may also be categorized on a continuum of unaware, resistant, neutral, supportive and leading [55]. The salient/primary stakeholders evident in light of interviews are households, municipalities, politicians, informal waste pickers, private scrap dealers, intermediaries and private sector waste management companies. These salient stakeholders cooperate to create value and at times compete for value created from waste management, indicating their self-interest. After all, it is not from their benevolence that we expect better waste management and recycling, but from their own interest in recyclables. A recurrent theme that emanated during analysis pertains to residents, who are generally uninterested in payment generated from waste. In lieu of this, however, they indiscriminately expect both the formal and informal waste management companies to fulfill their collection responsibilities of waste from their doorstep. In the majority of instances, the informal collectors and scavengers are extended financial help by residents as charity during the month of Ramadan with zakat, i.e., annual charity at a rate of 2 percent of total wealth payable by rich people. Such benevolence is, however, not available to personnel of formal waste management companies. The littering and garbage disposal patterns of stakeholders differ across time and space in various cities of Pakistan. Moreover, the study shows that the particular regulations and guidelines for the functioning of the system is the central factor that averts the stakeholders from completely implementing their contributions. Likewise, the trust deficit is another important reason for little cooperation among stakeholders due to competing interests. Hence, the legal structure with particular rules and regulations in 
the form of an ordinance for the creation of a recycling commission is required. Furthermore, the rules and regulations should be applied and executed constantly to successfully mobilize the contribution of relevant stakeholders for building trust, which is significant to enhanced coordination among stakeholders.

Table 4. Solid waste generation in major cities of Pakistan, according to the Bureau of Statistics (2019).

\begin{tabular}{ccc}
\hline City & Population & $\begin{array}{c}\text { Solid Waste } \\
\text { Generation/Daily with Tons }\end{array}$ \\
\hline Karachi & $20,500,000$ & 9440 \\
Lahore & 10.000 .000 & 6510 \\
Faisalabad & $7,500,000$ & 4883 \\
Rawalpindi & $5,900,000$ & 3841 \\
Hyderabad & $5,500,000$ & 3581 \\
Multan & $5,200,000$ & 3385 \\
Gujranwala & $4,800,000$ & 3125 \\
Sargodha & $4,500,000$ & 2930 \\
Peshawar & $2,900,000$ & 1888 \\
Quetta & 600,000 & 326 \\
\hline
\end{tabular}

Source: Bureau of Statistics, 2018 [56].

The empirical evidence generated from the interviews with stakeholders indicates that both stakeholder categories use traditional ways of waste collection in Lahore, Pakistan. Almost all private firms are recruiting on daily basis via daily wages for collecting waste material. Most of the firms are trying to adopt new technology and the latest equipment for controlling waste management processes, specifically for hazardous waste material, but not the autonomous informal stakeholders. The private sector companies mainly used customized compositing, gasification technology, pyrolysis technology for PET bottles and incinerators to avoid cross-contamination. Likewise, the study shows that mostly firms are concerned regarding their employees. The results given in Table 2 indicate that Gujranwala Waste Management Company is the pioneer among all others, founded in 2004. This company collects 2841 tons of overall waste per day. The Ozkatallar Company founded in 2008 in various parts of Punjab collects overall 4583 tons of waste in a day. Their waste collection is higher than Gujranwala Waste Management Company due to expanded operations in many parts of the Punjab province. The OzPak Waste Management Company was founded in 2009 and works in many cities of the Punjab province and collects more waste in a day than the preceding two companies. Their average waste collected per day is estimated to be around 10,510 tons from all of its operating sites. The fourth company of our study sample is Lahore Waste Management, founded in 2010 in the capital city of the Punjab province. They collect 8340 tons of waste from Lahore city per day, which is higher than the first company that also operates in a single city. The fifth company of our study sample is A.T. Waste Management Company, which is operating in various parts of Pakistan.

The empirical evidence generated from interviews reveal that many of the items listed in Table 3 have more than one use in terms of waste reduction, re-use and recycling. Waste items from wood are used in manufacturing of check boards, laminated boards and plywood. Likewise, plastic bottles are used for the resale of petrol and kerosene in small quantities as well as in the production of polyester for clothes, bags and ropes. Black glass is more valuable than white glass in terms of recycling. Newspapers of foreign languages, though very toxic due to chemical ink, are mostly used in packaging and parcel services of food-related items in lieu of costly paper napkins. Local newspapers are seldom used due to the fact they contain holy verses and sacred names of the Muslim faith. Hence, a market for the import of foreign newspapers exists, although it may also contain sacred verses which are beyond the understanding of local people. Some types of bones are collected, crushed and grinded for use in manufacturing cutlery plates and other ornaments of high quality. Moreover, electronic scrap equipment is broken down to collect expensive cooper 
ore as well as silver, gold and iron through creative sorting mechanisms which involve manual labor work. Various metals such as iron and silver, steel and copper are sent back to nearest factories for recycling. Other than this, waste electrical and electronic equipment such as TVs, fridges, hard disk drives (HDDs) and cell phones are recycled for rare earth elements (REEs) and magnets. In general, the transportation of waste from residents or commercial shops to ultimate recycling plants changes many hands, resulting in higher transportation costs as a percentage of the recyclables' overall worth. Food waste such as organic kitchen waste is mostly used as cattle fodder due to the shrinkage of farm land in Lahore city, which is an alternative income source for waste pickers who also trade cattle. Discarded tires are used for manufacturing shoe soles and leftovers are sent for burning in brick kilns due to extended burning spans, although very toxic in nature. Some of the other valuable items include human hair, used for wig making and hair medicine and color testing. The least attractive recycling item in terms of profit margin is the leather of sacrificial animals amidst the fact that it is estimated that more than 100,000 animals are slaughtered during the Eid Al Azha sacrifice festival in Lahore. Finally, some items such as cast brass plated in chrome are extracted from sanitary tapes which are oftentimes stolen by addicts. Since the transportation of recyclables involve the transportation of huge amounts of compressed items by trucks and lorries, this practice has adverse impacts on roads due to excessive loads taken from scrap dealers to recycling plants. Moreover, the trucks are overloaded with compressed material which also serves as the easiest way to smuggle illegal items, but no conclusive evidence was obtained in this regard.

As evident from Table 4, with a population of over 10 million Lahore is the second most waste-generating city in Pakistan. This is mainly due to a corresponding higher population density per square kilometer than other parts of country. It has been observed that informal and unregulated value chains of scrap dealers termed as kebaryan facilitate illegal activities of theft by acting as an avenue for trade of stolen items such as cars, bikes and electronic appliances, among others. The majority of our interviewees had interacted with these people but many of their hidden suppliers were addicts who had a tendency to steal for hedonic pleasures. These items are broken down into parts and sold in second-hand replacement or spare parts markets in Lahore and elsewhere in Pakistan, feeding a large market for second-hand apparel, appliances and parts. The existence of readily available car and other electronic spare parts in Lahore serves as a testament to this finding in Pakistan. The working of kebaryan scrap dealers also supports the production of counterfeit products due to the collection of packing materials of engine oil (jerrycans) and shampoo bottles as well as tap and sanitary ware, which are mostly stolen due to their higher per unit price. The data suggest that there is evidence that such scrap dealers have multiple tiers of suppliers who contribute value to recycling in productive and unproductive ways. This is in concurrence that value creation through entrepreneurship can be both productive and unproductive, as well as destructive [57]. For instance, an engine oil change requires gallons (jerrycans) of branded car engine oils. Most of the time, the mechanic retains the jerrycan as well as provides free service in lieu of old oils and even spare parts. Even some of these items are imported from China, which has reduced the demand for recyclables collected by kebaryans. The empirical evidence reveals that shampoo bottles and engine oil jerrycans are used for production and sale of sub-standard replica products. Moreover, the scrap dealing business also performs a reusing function as Pakistan is a big trade market of second-hand articles ranging from reconditioned cars, computers, laptops, cell phones and small value items such as shoes and clothes imported from advanced countries. These products are readily consumed by the general public due to lower prices and usefulness which is still better than locally manufactured items in Pakistan, although post-COVID-19, there seems to be a decline due to fear of catching virus in the minds of public. 


\section{Discussion}

We have thus far established that waste management in Pakistan is a combination of formal and informal waste management stakeholders who work within their limitations. While informal waste management is performed mostly by unprivileged groups in urban areas, formal waste management comprises firms with formal structures, mechanisms and capital-intensive equipment, mostly functioning in urban areas such as Lahore. Informal waste pickers as well as heroin and ice addicts are a part of this sector because of various socio-economic factors, which exposes them to waste hazards and poisonous materials, posing serious health risks. The process framework of formal and informal recycling of waste is contrasted in Figure 1; Figure 2 to offer a better understanding. It can be seen that both formal and informal collection involves residents and collectors that transfer the waste to a middle man. In informal collection, the waste is sent to sorting centers and subsequently end up in recycling plants after passing through several intermediaries. The material flow and cash flow is indicated at all parts of the collection. However, it has been learnt that the intermediaries are greater in number than those represented in Figure 1, as recyclable items can be collected by autonomous Rikshaw drivers, shop keepers and part timers, as well as brought to a larger "kebaryia" scrap shop by the residents, their servants and maids in a self-organized manner due to value laden in the sale of such items. This process is accompanied by variations in prices of collected items as the recyclables move from the supplier end towards the buyers-buyer end. Unlike in developed countries, the information carried by the product in the form of RFID tags and barcodes is conspicuous by its absence in Lahore due to the low level of sophistication in collection approaches [58]. A closer look at formal collection allows us to know that waste is directly gathered from residents. The collector transfers it to companies and the company may be paid by the resident or the concerned party. This offers better cash flow in comparison to informal waste collectors.
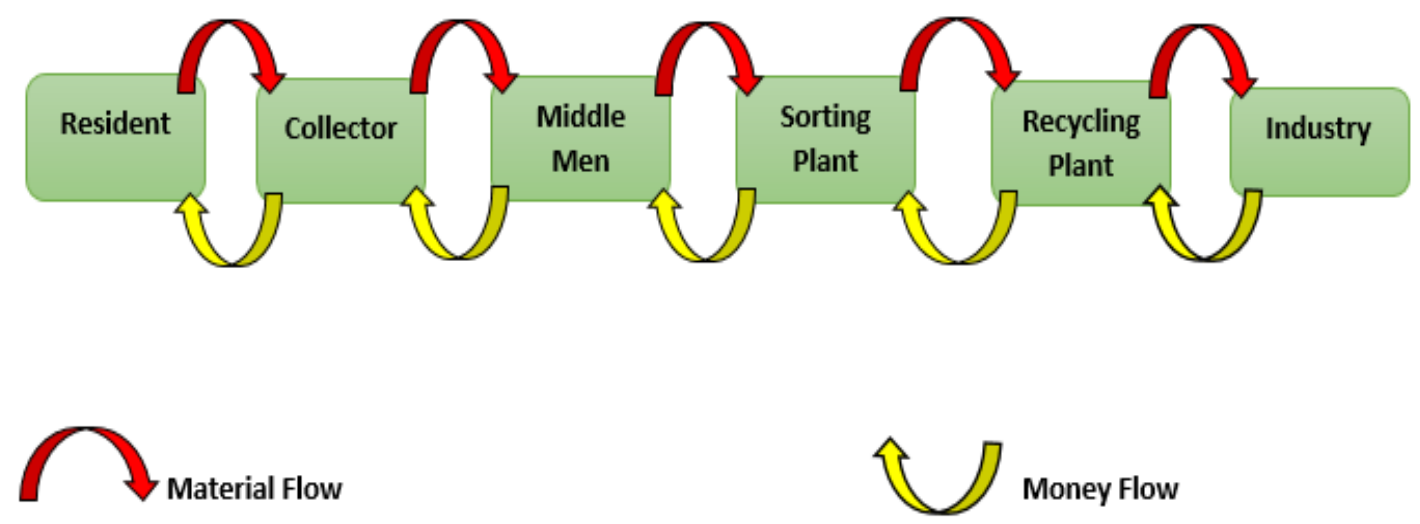

Figure 1. The process of informal waste collection.

Despite the merits of the informal sector, the formal sector holds a bias towards informal workers, which acts as barrier to integration efforts undertaken in the past. These biases are due to bounded rationality and limited information processing capacities, in line with societal norms [59]. At the policy level, if due recognition and inclusion of informal waste collectors as key stakeholders are ensured, this would result in greater complementarities in waste management [8]. Furthermore, the current study suggests that formal waste management practices in Pakistan are not comparable to contemporary intelligent waste collection systems across the world [60]. The study also helped in the identification process of waste management, recycling and cash flow between entities involved in formal collections systems in Pakistan. It can be said that the process of formal collection of waste and cash flow is a complicated phenomenon in the context of formal waste management companies. It is obvious from Figure 2 that normally between generator and collector, the collection of money takes place. Such a system, if integrated under the law by a recycling commission, will help integrate the efforts contrasted in the two process 
frameworks of formal and informal recycling in Lahore. While the generator and server are responsible for booking of appointments and offer credits in cash flow, the application servers are responsible to give orders to the collectors and send information about orders and flow of waste, as shown in Figure 2. However, in certain instances, the residents may only be interested in the disposal of waste and related services and not the associated credit in cash and kind in urban areas of Lahore.

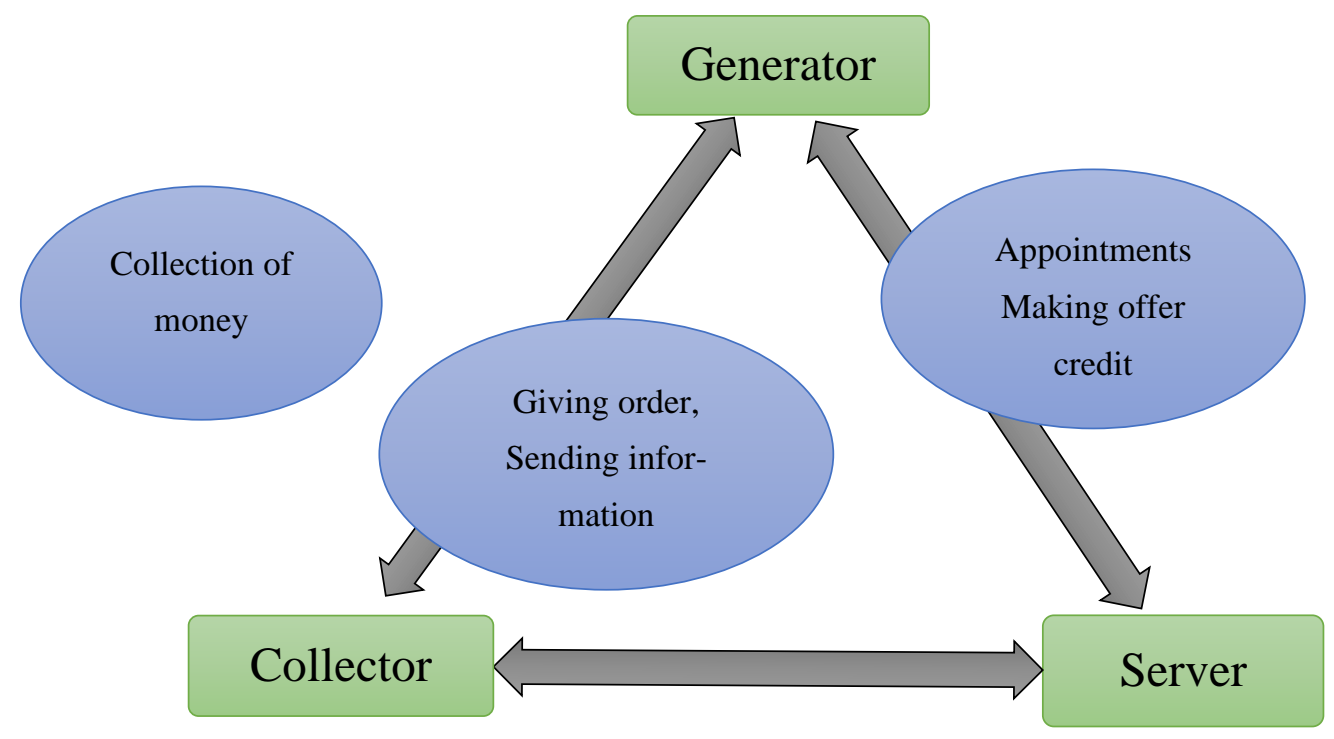

Figure 2. The two-way process of formal collection.

Multiple stakeholders are involved in waste management and recycling in the context of Pakistan, whose integration presents a grand challenge [50]. Stakeholders may cause waste (such as the general public), work as service suppliers or engage in this sector as a state, local government department or NGO concerned with the definite features of waste management [44]. More robust collaboration and reciprocity among various stakeholder groups enhances the efforts undertaken to reduce overall waste and to infuse a spirit of sustainable living by practicing segregation at the source [61]. However, the informal sectors in many countries directly provide the services related to waste collection [20]. These include individual or group collection through door-to-door service for collecting wasted materials from institutions and households by using donkey carts, hand carts, bicycles or other small vehicles. The main motive is economic value extraction in return for services to the public. These stakeholders generate income after selling the recyclable/reusable fractions collected in the waste material [62]. Upon collection, the material deemed valuable is cleaned, segregated, washed, classified and dried for onward trade which is informal in nature. The residual organic waste has often been used for the purpose of the feeding stocks for domestic animals such as goats or used as a soil supplement for the agricultural sector through composting. Some fraction of the waste is utilized by the collector working for an employer and contractor who may not want to buy valuable items found in waste. In the exchange of the waste collection, the collectors and contractors are also given wages and shelter [20]. In addition, the secondary raw material is segregated and recovered from the vehicle transporting the MSW to the disposal zones [62]. These forms of resource recoveries are pronounced in developing such as Columbia, Thailand, the Philippines and Mexico [63].

Moreover, the kabarias (junk shop dealers) and the middlemen play important roles in the recycling of the materials as they procure the recyclables with cash $[64,65]$. The scavengers have choices of selling recyclables to specific or any dealers and may enter into agreements with the kabarias who also extend credit to such people [8]. All the junk shops in an area are surveyed to confirm the price of the recyclable goods by the scavengers. The junk shop dealer either sells the recyclable to small cottage industries or to middlemen 
and waste traders who sell to the recycling and manufacturing industries depending on location and type. The primary as well as secondary dealers, junk shops, nascent dealers, intermediate processors, wholesalers and brokers all constitute the middlemen intermediaries [62]. These groups play important roles in recycling material to cater to demands of industries by providing timely volumes of quality materials. Above all, the positive and most important roles in the management of the waste of the developing countries are played by the scavengers [66]. The scavengers are known by various names in local languages of a country [63]. Scavenger, garbage trucks helpers and the itinerant buyers are the main players in the private sector working informally [66]. Waste picking is an important source of income and represents a safety net for poor peoples of developing countries [67]. The authors of [20] had noted that in a few cases, the wastes pickers had to pay to access the wastes and thereafter to sell the material to some organization at a price much less than the market value. However, grouped or family-organized activity reduces the individual vulnerabilities and exploitations by providing levels of economic/social support to waste pickers [62].

Among direct and indirect stakeholders, the social, political and religious leaders are also vital players in encouraging the desired action in order to lobby for a recycling commission or agency, whichever is effective in handling MSW. Many political parties, including religious prayer leaders, often collect hides of sacrificial animals during the Eid $\mathrm{Al}$ Azha sacrifice festival in Lahore. According to [68], around 8 million animals are sacrificed in Pakistan, which serves as a major source of leather collection for charity collectors. In recent years, the price of skin hides in international markets has been very low due to the fact that many tanners in other countries obtain hides free of cost. Private sector waste management enterprises are a relatively new phenomenon in the context of formal waste management systems in Pakistan. These companies are by far more efficient in terms of their coverage, visibility, recyclability capabilities and operating procedures. Their workers are hired on a contractual basis and perform better than their counterparts in the public sector. Consequently, the untidy nature of work and associated stigma compels workers to consider job hopping when an opportunity arises in a more respectable profession. Part of the problem, as the data suggest, is the role conflict created due to the fact that to have a clean ecosystem, someone has to be a janitor/cleaner or friend of the environment, such as sustainopreneurs. Given their small-scale operations, these companies are unable to offer a complete solution. The government is considering furthering its private-public partnership by considering options of involvement of international companies of waste management in the future. Even then, local private sector companies are better poised than international companies due to cultural, religious and societal peculiarities in Pakistan.

\section{Conclusions}

A highly creative process of waste recycling is present across Pakistan, where value exploration, extraction and value delivery occur through careful segregation, consolidation and distribution of recyclables. Comparatively, the level of recycling in Lahore is more sophisticated than other major cities of the country. The informal and unregulated waste recycling chains co-exist to offset the challenges posed by the lack of formal recycling mechanisms in Lahore, Pakistan. The process of value extraction through recycling occurs through the transportation of valuable items in large consolidation quantities from scrap dealers to recycling plants, which takes a toll on the roads as well as serves as a potential avenue for the smuggling of illegal goods, and plays a role in the manufacture of counterfeit products due to the lack of monitoring and control. The transportation of waste by way of its nature goes unhindered from the suppliers-supplier to the buyers-buyer of waste value chains for recycling purposes due to the lack of a monitoring apparatus with law and enforcement authorities. Most alarmingly, the sale of sub-standard counterfeit products and replicas as well as illegal spare parts of machinery, cars and other items exists. As a result, a second-hand market is present across Lahore and throughout Pakistan, supported by informal waste assemblers and recyclers whose source is neighboring Afghanistan. 
In terms of international law and treaties, the transit trade from Karachi to Kabul offers gray channels for the return of such materials to neighboring countries instead of their original destination. Although a significant level of recycling is achieved in respect to many solid waste components, materials such as Pampers and Tetra packaged items have low recyclable value and occupy a lot of space in sanitary landfills. The stakeholders both direct and indirect seem to be unaware of the long-term ramifications of their businesses on themselves and society. The integration of formal and informal practices is possible through the creation of a separate recycling agency/commission with adequate support of developed countries to lessen the common burden of environmental conservation and sustainability.

A common practice is to merge the pre-existing informal sector with the newly formed formal sector to make use of their experience, while forming a new recycling management plan. Their inclusion through a policy of gradual progression into formal jobs will likely improve prospects of integration efforts. Finally, the role of private waste management companies has been better than government counterparts amidst their small-scale operations and slow growth in the past decade. The success of public-private partnership has led to considerations of hiring services of international waste management companies with foreign workers who do not consider waste collection a taboo, which is a prevalent cultural and social barrier in Pakistan. Due to high levels of state intervention in solid waste management and recycling, it has become more of a socio-economic issue than a technical one. Moreover, numerous stakeholders are engaging in the waste management sector. We determined through this study that politicians prefer low-tech solutions due to low income and low job creation in comparison to higher levels of formal mechanization, which yields lower job creation. There have been few efforts to integrate waste collection procedures by recognizing informal sector workers as key stakeholders in the solid waste management system, which this study strives to advocate. Moreover, the role of informal sector waste scavengers is crucial in the wake of an inefficient public sector workforce in regards to waste recycling. The importance of formal sector companies through publicprivate partnership has been gradually on the rise amidst their small-scale operations and service delivery capacity in Lahore, Pakistan.

\section{Recommendations}

This study recommends the creation of a central authority in the form of a commission to overlook and regulate the affairs of hitherto unregulated municipal solid waste and recycling value chains in Pakistan. This would also overcome the inherent bias towards informal sector waste collectors and serve as a first step towards their possible inclusion in the formal sector, and the improvement of intermediaries associated with the recycling sector whose work is buried under the grandiosity of public sector progress reports. Moreover, a central commission would be able to overlook issues related to gray traffic under the guise of recyclables as well as act as a theft deterrent while improving law and order conditions through monitoring mechanisms. Moreover, the commission would also serve as platform for grievances of waste recycling firms in regard to seamless logistics operations through trucks and lorries to designated recycling factories. Finally, the number of intermediaries in recycling value chains and associated stakeholders' rights would be best upheld through formal transition paths from the informal sector to the formal sector in a guided manner.

Author Contributions: M.N., writing—original draft preparation, conceptualization, formal analysis, data curation. M.T.Y., methodology, writing—review and editing. M.S., investigation, software. M.S., visualization, software. W.A., methodology, resources. H.H., project administration, supervision, funding acquisition. A.A.-M., project administration, funding acquisition. A.V.-M., resources, funding acquisition. S.K., project administration, resources, software. All authors have read and agreed to the published version of the manuscript.

Funding: Independent project. 
Institutional Review Board Statement: Not applicable.

Informed Consent Statement: Not applicable.

Data Availability Statement: Not applicable.

Conflicts of Interest: There is no conflict of interest.

\section{References}

1. Moh, Y. Solid waste management transformation and future challenges of source separation and recycling practice in Malaysia. Resour. Conserv. Recycl. 2017, 116, 1-14. [CrossRef]

2. Forrest, A.; Giacovazzi, L.; Dunlop, S.; Reisser, J.; Tickler, D.; Jamieson, A.; Meeuwig, J.J. Eliminating plastic pollution: How a voluntary contribution from industry will drive the circular plastics economy. Front. Mar. Sci. 2019, 6, 627. [CrossRef]

3. Worldometer. 2021. Available online: https://www.worldometers.info/world-population/pakistan-population/ (accessed on 4 February 2021)

4. Aparcana, S. Approaches to formalization of the informal waste sector into municipal solid waste management systems in lowand middle-income countries: Review of barriers and success factors. Waste Manag. 2017, 61, 593-607. [CrossRef]

5. Orlins, S.; Guan, D. China's toxic informal e-waste recycling: Local approaches to a global environmental problem. J. Clean. Prod. 2016, 114, 71-80. [CrossRef]

6. Costa, I.; Massard, G.; Agarwal, A. Waste management policies for industrial symbiosis development: Case studies in European countries. J. Clean. Prod. 2010, 18, 815-822. [CrossRef]

7. Massoud, M.A.; El-Fadel, M.; Malak, A.A. Assessment of public vs. private MSW management: A case study. J. Environ. Manag. 2003, 69, 15-24. [CrossRef]

8. Yousafzai, M.T.; Nawaz, M.; Xin, C.; Tsai, S.B.; Lee, C.H. Sustainability of waste picker sustainopreneurs in Pakistan's informal solid waste management system for cleaner production. J. Clean. Prod. 2020, 267, 121913. [CrossRef]

9. Nawaz, M.; Yousafzai, M.T.; Shah, T.; Xin, C.; Ahmad, W. Sustainability of Recycling Waste Picker Sustainopreneurs for Prevention and Mitigation of Municipal Solid Waste in Swat. Sustainability 2021, 13, 6533. [CrossRef]

10. Darbi, W.P.K.; Hall, C.M.; Knott, P. The Informal Sector: A Review and Agenda for Management Research. Int. J. Manag. Rev. 2018, 20, 301-324. [CrossRef]

11. Katusiimeh, M.W.; Burger, K.; Mol, A.P. Informal waste collection and its co-existence with the formal waste sector: The case of Kampala, Uganda. Habitat Int. 2013, 38, 1-9. [CrossRef]

12. Ilomäki, M.; Melanen, M. Waste minimization in small and medium-sized enterprises-Do environmental management systems help? J. Clean. Prod. 2001, 9, 209-217. [CrossRef]

13. Masood, M.; Barlow, C.Y.; Wilson, D.C. An assessment of the current municipal solid waste management system in Lahore, Pakistan. Waste Manag. Res. 2014, 32, 834-847. [CrossRef]

14. Lum, Z.-A. 99 Per Cent of Sweden's Garbage Is Now Recycled, Huffington Post. Available online: http:/ / www.lifelcip.eu/EN/ fiche-actualite/56/99-Per-Cent-Of-Sweden-s-Garbage-Is-Now-Recycled- (accessed on 8 May 2021).

15. Wefuturecycle Waste Management in Germany, 87\% Recycling Rate. Available online: https://wefuturecycle.com/2015/07/15 / waste-management-in-germany-87-recycling-rate/ (accessed on 8 May 2021).

16. Carter, K. Wales Records Another Recycling Leap to 62 Per Cent Rate, Resource. Available online: https:/ / www.letsrecycle.com/ news / welsh-councils-set-to-hit-60-recycling/ (accessed on 8 May 2021).

17. Troschinetz, A.M.; Mihelcic, J.R. Sustainable recycling of municipal solid waste in developing countries. Waste Manag. 2009, 29, 915-923. [CrossRef] [PubMed]

18. Masood, M.; Barlow, C.Y. Framework for integration of informal waste management sector with the formal sector in Pakistan. Waste Manag. Res. 2013, 31, 93-105. [CrossRef] [PubMed]

19. Hartmann, C. Waste picker livelihoods and inclusive neoliberal municipal solid waste management policies: The case of the La Chureca garbage dump site in Managua, Nicaragua. Waste Manag. 2018, 71, 565-577. [CrossRef] [PubMed]

20. Asim, M.; Batool, S.A.; Chaudhry, M.N. Scavengers and their role in the recycling of waste in Southwestern Lahore. Resour. Conserv. Recycl. 2012, 58, 152-162. [CrossRef]

21. Kahn, J. State of Municipal Solid Waste Management in Pakistan: A Case Study of Haripur District. Ph.D. Thesis, Kingston University, London, UK, 2016.

22. Umair, S.; Björklund, A.; Petersen, E.E. Social impact assessment of informal recycling of electronic ICT waste in Pakistan using UNEP SETAC guidelines. Resour. Conserv. Recycl. 2015, 95, 46-57. [CrossRef]

23. Scheinberg, A. Value Added: Modes of Sustainable Recycling in the Modernisation of Waste Management Systems. Ph.D. Thesis, Wageningen University, Wageningen, The Netherlands, 2011.

24. Raimundo, I.; Crush, J.; Pendleton, W. Food insecurity, poverty and informality. In Rapid Urbanisation, Urban Food Deserts and Food Security in Africa; Springer: Cham, Switzerland, 2016; pp. 71-83. [CrossRef]

25. Yamamoto, T. Linkage of Municipal Solid Waste Management and Peacebuilding: A Case Study in Northern Jordan Affected by Syrian Refugee Influx. Development 2019, 19, 20. [CrossRef]

26. Percot, M. Picking up the neighbours' waste: Migration of Bangladeshi villagers to India metropolises. Migr. Dev. 2020, 9, 43-55. [CrossRef] 
27. Salem, M.; Raab, K.; Wagner, R. Solid waste management: The disposal behavior of poor people living in Gaza Strip refugee camps. Resour. Conserv. Recycl. 2020, 153, 104550. [CrossRef]

28. Korai, M.S.; Mahar, R.B.; Uqaili, M.A. The feasibility of municipal solid waste for energy generation and its existing management practices in Pakistan. Renew. Sustain. Energy Rev. 2017, 72, 338-353. [CrossRef]

29. Schenck, C.J.; Blaauw, P.F.; Viljoen, J.M.M. The socio-economic differences between landfill and street waste pickers in the Free State province of South Africa. Dev. South. Afr. 2016, 33, 532-547. [CrossRef]

30. Medina, M. Scrap and Trade: Scavenging Myths. 2010. Available online: https://ourworld.unu.edu/en/scavenging-from-waste (accessed on 12 June 2021).

31. Majeed, A.; Batool, S.A.; Chaudhry, M.N. Environmental quantification of the existing waste management system in a developing world municipality using EaseTech: The case of Bahawalpur, Pakistan. Sustainability 2018, 10, 2424. [CrossRef]

32. Tariq, M. Developing Entrepreneur Capacities Through Higher Education: Learning for Value Creation. Ph.D. Thesis, Qurtuba University of Science \& Information Technology, Peshawar, Pakistan, 2018.

33. Biyani, N.; Anantharaman, M. Aligning Stakeholder Frames for Transition Management in Solid Waste: A Case Study of Bangalore. Int. Dev. Policy Rev. Int. Polit. Dev. 2017. [CrossRef]

34. Sue, D.C.; Chuang, C.C. Engineering design and exergy analyses for combustion gas turbine based power generation system. Energy 2004, 29, 1183-1205. [CrossRef]

35. Marshall, R.E.; Farahbakhsh, K. Systems approaches to integrated solid waste management in developing countries. Waste Manag. 2013, 33, 988-1003. [CrossRef] [PubMed]

36. Pariatamby, A.; Fauziah, S.H. Sustainable 3R practice in the Asia and Pacific Regions: The challenges and issues. In Municipal Solid Waste Management in Asia and the Pacific Islands; Springer: Singapore, 2014; pp. 15-40.

37. Hilmi, M. Recapturing value from waste for developing green food value chains. Middle East J. 2019, 8, $268-297$.

38. Menikpura, S.N.M.; Gheewala, S.H.; Bonnet, S. Framework for life cycle sustainability assessment of municipal solid waste management systems with an application to a case study in Thailand. Waste Manag. Res. 2012, 30, 708-719. [CrossRef]

39. Singh, G.K.; Gupta, K.; Chaudhary, S. Solid waste management: Its sources, collection, transportation and recycling. Int. J. Environ. Sci. Dev. 2014, 5, 347. [CrossRef]

40. Allwood, J.M. Squaring the Circular Economy: The Role of Recycling within a Hierarchy of Material Management Strategies. In Handbook of Recycling: State-Of-The-Art for Practitioners, Analysts, and Scientists; Newnes: Lithgow, Australia, 2014. [CrossRef]

41. Liu, J.; Ding, F.Y.; Lall, V. Using data envelopment analysis to compare suppliers for supplier selection and performance improvement. Supply Chain Manag. 2000, 5, 143-150. [CrossRef]

42. Ravindra, K.; Kaur, K.; Mor, S. System analysis of municipal solid waste management in Chandigarh and minimization practices for cleaner emissions. J. Clean. Prod. 2015, 89, 251-256. [CrossRef]

43. Hannan, M.A.; Abdulla Al Mamun, M.; Hussain, A.; Basri, H.; Begum, R.A. A review on technologies and their usage in solid waste monitoring and management systems: Issues and challenges. Waste Manag. 2015, 43, 509-523. [CrossRef]

44. Joseph, K. Stakeholder participation for sustainable waste management. Habitat Int. 2006, 30, 863-871. [CrossRef]

45. Xiao, S.; Dong, H.; Geng, Y.; Brander, M. An overview of China's recyclable waste recycling and recommendations for integrated solutions. Resour. Conserv. Recycl. 2018, 134, 112-120. [CrossRef]

46. Leitch, C.M.; Hill, F.M.; Harrison, R.T. The philosophy and practice of interpretivist research in entrepreneurship: Quality, validation, and trust. Organ. Res. Methods 2010, 13, 67-84. [CrossRef]

47. Rousseau, D.; Billingham, J. A systematic framework for exploring worldviews and its generalization as a multi-purpose inquiry framework. Systems 2018, 6, 27. [CrossRef]

48. Hazard, L.; Cerf, M.; Lamine, C.; Magda, D.; Steyaert, P. A tool for reflecting on research stances to support sustainability transitions. Nat. Sustain. 2019, 3, 89-95. [CrossRef]

49. Head, B.W. Forty years of wicked problems literature: Forging closer links to policy studies. Policy Soc. 2019, 38, 180-197. [CrossRef]

50. Eisenhardt, K.; Graebner, M.; Sonenshein, S. From the Editors Grand Challenges and Inductive Methods: Rigor Without Rigor Mortis.: Ebscohost. Acad. Manag. J. 2016, 59, 1113-1123. Available online: https://web-b-ebscohost-com.proxy.bc.edu/ ehost/pdfviewer/pdfviewer?vid=1\&sid=5fa3f004-27e0-4668-ad22-c912044baa49\%40pdc-v-sessmgr04 (accessed on 15 July 2021). [CrossRef]

51. Creswell, J.W.; Poth, N.C. Qualitative Inquiry and Research Design: Choosing among Five Approaches; Sage Publications: New York, NY, USA, 2017.

52. Charmaz, K. Reconstructing grounded theory. In The SAGE Handbook of Social Research Methods; Sage Publications: New York, NY, USA, 2008; pp. 461-478.

53. Flick, U. Qualitative inquiry-2.0 at 20? Developments, trends, and challenges for the politics of research. Qual. Inq. 2015, 21, 599-608. [CrossRef]

54. Iqbal, T.; Yousafzai, M.T.; Ali, S.; Sattar, K.; Saleem, M.Q.; Habib, U. There's No Such Thing as Free Lunch but Envy among Young Facebookers. KSII Trans. Internet Inf. Syst. TIIS 2018, 12, 4724-4737. [CrossRef]

55. Bayona, S.; Bustamante, J.; Saboya, N. PMBOK as a Reference Model for Academic Research Management. In World Conference on Information Systems and Technologies; Springer: Cham, Switzerland, 2018; pp. 863-876. 
56. Bureau of Statistics 2018, Pakistan Statistical Yearbook. Available online: http://www.statistics.gov.pk/assets / publications/2 psyb_2015.pdf (accessed on 7 June 2021).

57. Baumol, W.J. Quality changes and productivity measurement: Hedonics and an alternative. J. Account. Audit. Financ. 1990, 5, 105-117. [CrossRef]

58. Tariq, M.; Khan, S.U. Organizational Integration for the Implementation of RFID: A Case Study of Philips Semiconductors Interdiscip. J. Contemp. Res. Bus. 2011, 3, 883-892.

59. Esmaeilian, B.; Wang, B.; Lewis, K.; Duarte, F.; Ratti, C.; Behdad, S. The future of waste management in smart and sustainable cities: A review and concept paper. Waste Manag. 2018, 81, 177-195. [CrossRef] [PubMed]

60. Xue, Y.; Wen, Z.; Bressers, H.; Ai, N. Can intelligent collection integrate informal sector for urban resource recycling in China? J. Clean. Prod. 2019, 208, 307-315. [CrossRef]

61. Bernstein, J.A.; Alexis, N.; Barnes, C.; Bernstein, I.L.; Bernstein, J.A.; Nel, A.; Peden, D.; Diaz-Sanchez, D.; Tarlo, S.M.; Williams, P.B. Health effects of air pollution. J. Allergy Clin. Immunol. 2004, 114, 1116-1123. [CrossRef] [PubMed]

62. Wilson, D.C.; Velis, C.; Cheeseman, C. Role of informal sector recycling in waste management in developing countries. Habitat Int 2006, 30, 797-798. [CrossRef]

63. Medina, M. Scavenger cooperatives in Asia and Latin America. Resour. Conserv. Recycl. 2000, 31, 51-69. [CrossRef]

64. Sembiring, E.; Nitivattananon, V. Sustainable solid waste management toward an inclusive society: Integration of the informal sector. Resour. Conserv. Recycl. 2010, 54, 759-1026. [CrossRef]

65. Ahmed, A.S.; Ali, M. Partnerships for solid waste management in developing countries: Linking theories to realities. Habitat Int. 2004, 28, 467-479. [CrossRef]

66. Pasang, H. The Role of Scavengers in Municipal Solid Waste Management in Jakarta, Indonesia; International Technologies Centre, Department of Civil and Environmental Engineering, Faculty of Engineering, The University of Melbourne: Melbourne, Australia, 2002.

67. EPMC. Data Collection for Preparation of National Study on Privatization of Solid Waste Management in Eight Selected Cities of Pakistan; Engineering Planning and Management Consultants (EPMC): Lahore, Pakistan, 1996.

68. Mallhi, T.H.; Khan, Y.H.; Alotaibi, N.H.; Alzarea, A.I.; Tanveer, N.; Khan, A. Celebrating Eid-ul-Adha in the era of COVID-19 pandemic in Pakistan: Potential threats and precautionary measures. Clin. Microbiol. Infect. 2020, 26, 1714. [CrossRef] [PubMed] 